\title{
A note on rearing calves on diets supplemented with evening primrose (Oenothera paradoxa) oil cake
}

\section{J.A. Strzetelski, J. Kowalczyk ${ }^{1}$, Barbara Niwińska, Katarzyna Krawezyk and Katarzyna Maciaszek}

\author{
Research Institute of Animal Production, \\ Department of Animal Physiology and Nutrition \\ 32-083 Balice, Poland \\ 'The Kielanowski Institute of Animal Physiology and Nutrition, \\ Polish Academy of Sciences \\ 05-110 Jablonna, Poland
}

(Received 26 June 1998; accepted 22 September 1998)

\begin{abstract}
The effect of substitution of soyabean oilmeal with evening primrose (Onothera paradoxa) oil cake was investigated on 60 bull calves from days 7 to 120 of age, divided into three groups: control, $\mathrm{C}$, fed with soyabean oilmeal as the main source of protein in the concentrate mixture; $\mathrm{Pl}, 50 \%$ soyabean oilmeal protein was substituted with the equivalent of evening primrose oil cake; $\mathrm{P} 2$, total protein of soyabean meal was substituted with protein of evening primrose oil cake. In the respective diets, the feed mixtures contained $0,16.5$ or $33 \%$ of evening primrose oil cake. The calves were given about $350 \mathrm{~kg}$ of whole milk from days 7 to 56 of life. The increased level of evening primrose cake in the diet augmented feed intake but was not reflected in body gains $(\mathrm{P}>0.05)$, and significantly decreased feed efficiency $(\mathrm{P}<0.01)$.
\end{abstract}

KEY WORDS: evening primrose oil cake, soyabean meal, calves, feed efficiency

\section{INTRODUCTION}

The nutritional value and effectiveness of feeding evening primrose oil cake as a component of the diets for fattened bulls and lactating cows was reported in previous papers (Stasiniewicz et al., 1998; Strzetelski et al., 1998a,b). The results of these experiments indicated that evening primrose oil cake can be used as an 
alternative complementary source of protein in beef and milk production having in mind its high content of methionine and cystine but low level of lysine. The high level of essential unsaturated fatty acids and, particularly, of biologically active $\gamma$-linolenic $\left(\mathrm{C}_{18: 3 \mathrm{ng}}\right)$ acid which is an intermediate metabolite of linoleic $\left(\mathrm{C}_{18: 2 \mathrm{ng}}\right)$ acid (Horrobin, 1990), in evening primrose oil cake makes this feed interesting as an additive to the diet for reared calves. Experiments on rats suggest that evening primrose oil cake is of limited significance in monogastric feeding as it contains antinutritive substances decreasing protein digestibility (Hanczakowski and Szymczyk, 1993). New-born calves could be considered as monogastric animals but the development of forestomachs and fermentation processes and nutrient digestibility in the rumen start relatively early. Rumen fermentation can modify antinutritive substances into less harmful compounds decreasing their negative effect on nutrients utilization in calves (Dixon and Hosing, 1992).

The aim of the present study was to assess the effectiveness of feeding rearing calves diets containing evening primrose oil cake.

\section{MATERIAL AND METHODS}

\section{Animals and feeding}

The experiment was carried out on 60 Black-and-White Lowland bull calves from 7 days of age at the beginning to 120 days of age at the end of the experiment. The animals were divided into 3 groups of 20 animals in each, allocated to the

TABLE !

Composition of concentrate mixtures (\%) and design of feeding calves with whole milk

\begin{tabular}{|c|c|c|c|c|c|}
\hline \multirow{2}{*}{ Item } & \multicolumn{3}{|c|}{ Groups } & \multicolumn{2}{|c|}{ Design of feeding with whole mik' } \\
\hline & $\mathrm{C}$ & P1 & $\mathrm{P} 2$ & age, weeks & whole milk, $\mathrm{kg} /$ day \\
\hline Ground barley & 60 & 30 & 17 & 6 days & colostrum ${ }^{2}$ \\
\hline Soyabean oilmeal & 15 & 8 & - & 2 & 8 \\
\hline Ground wheat & 10 & 14 & 8 & 3 & 8 \\
\hline Wheat bran & 13 & 29.5 & 40 & 4 & 8 \\
\hline Evering promrose oil coke & 16.5 & 33 & 5 & 5 & 8 \\
\hline \multirow[t]{3}{*}{ Mineral mixture' } & 2 & 2 & 2 & 6 & 8 \\
\hline & & & & 7 & 6 \\
\hline & & & & 8 & 3 \\
\hline
\end{tabular}

1 composition, \%: limestone, 25; common salt, 15; Polfamix CJ, 25; commercial mineral mixture MMB, 35

in $1 \mathrm{~kg}, \mathrm{~g}$ : Ca 127, $\mathrm{Na} 98, \mathrm{Cl} 91, \mathrm{Cu} 0.63, \mathrm{Mn} \mathrm{L} .58, \mathrm{Zn} 2.1, \mathrm{P} 57, \mathrm{Mg} \mathrm{16.3,} \mathrm{J} \mathrm{0.007,} \mathrm{flavomycin}$ 0.29 and vit. $\mathrm{D}_{3} 10.75 \mathrm{IU}$

2 colostrum 4-6 kg, 3 times per day, at the first day $-2 \mathrm{~kg}$ beetwen 2 and $6 \mathrm{~h}$ of life 
appropriate groups successively as they were calved. The animals were kept in individual stalls with slatted floor with automatic drinking bowl and fed concentrate mixtures ad libium and meadow hay $0.1 \mathrm{~kg} / \mathrm{day}$ in the milk period and afterwards $0.2 \mathrm{~kg} /$ day. Calves received about $350 \mathrm{~kg}$ of whole milk from days 7 to 56 of life. The scheme of feeding calves with milk and composition of experimental feed mixtures (Table 1) was according to INRA system (IZ, 1993).

The main source of protein in the diet for calves of the control group (C) was soyabean oilmeal, in the second group (P1) $50 \%$ of soyabean oilmeal protein was substituted with respective amounts of evening primrose oil cake protein, and in the third group $(\mathrm{P} 2)$ all of the protein of soyabean was substituted with the appropriate amount of evening primrose oil cake protein.

Feed intake was controlled daily and body liveweight of calves was controlled for two successive days at the beginning of the experiment (7 day of age), at the end of milk period ( 56 day of age) and at the end of experiment ( 120 days of age).

\section{Chemical analysis and statistics}

Proximate chemical analysis of feeds was carried out according to AOAC (1990) methods. The nutritive value of feeds and expcrimental feed mixture composition were set up using INWAR ver. 1.0, and INRAtion ver. 2.62 (1993) software systems. The coefficient of protein degradability in the rumen deg $=0.39$ and intestinal digestion of protein undegraded in the rumen $\mathrm{ds} i=0.65$ were determined according to the method of Michalet-Doreau et al. (1987).

The results were subjected to statistical analysis using one way analysis of variance estimating the significance of differences between groups with multiple interval test according to the Statgraphics Plus 6.0 (1992) software system.

\section{RESULTS}

The level of crude protein was similar in all mixtures, but that of PDI and energy in the mixture was higher in the experimental feed mixtures ( $\mathrm{P} 1$ and $\mathrm{P} 2$ ) than in the control (C). The fat, crude fibre content and feed intake increased with the higher proportion of evening primrose oil cake in feed mixtures (Tables 2 and 3 ). The daily intake of nutrients and concentrate mixtures was the highest in group P2 and the lowest in group C, but intake of UFL, PDI and difference between PDIE and PDIN were similar $(\mathrm{P}>0.05)$ in all groups. Differences in body liveweight gain both in the milk period as well as in the whole period of rearing were statistically insignificant (Table 4). However, the body gain of calves of group P2 in the entire experimental period was about $4 \%$ less than of these in groups $\mathrm{C}$ and $\mathrm{P} 1$. Feed utilization for body gain was the best in $\mathrm{C}$ and worst in group $\mathrm{P} 2$. 
TABLE 2

Chemical composition and nutritive value of feeds according to INRA system

\begin{tabular}{|c|c|c|c|c|c|c|c|c|}
\hline \multirow{3}{*}{ Feed } & \multicolumn{5}{|c|}{ Chemical composition, $\%$} & \multicolumn{3}{|c|}{$\begin{array}{l}\text { In } 1 \text { kg of dry matter } \\
\text { (INRA system') }\end{array}$} \\
\hline & \multirow{2}{*}{$\begin{array}{l}\text { dry } \\
\text { matter }\end{array}$} & \multirow{2}{*}{$\begin{array}{l}\text { crude } \\
\text { protein }\end{array}$} & \multirow{2}{*}{$\begin{array}{l}\text { ether } \\
\text { extract }\end{array}$} & \multirow{2}{*}{$\begin{array}{l}\text { crude } \\
\text { fibre }\end{array}$} & \multirow[t]{2}{*}{ ash } & \multirow[t]{2}{*}{ UFL } & \multicolumn{2}{|c|}{ PDJ, g } \\
\hline & & & & & & & PDIN & PDIE \\
\hline Ground barley & 88.05 & 9.69 & 2.26 & 4.96 & 2.18 & 1.18 & 72 & 100 \\
\hline Soyabean oilmeal & 88.29 & 42.92 & 2.22 & 5.64 & 6.80 & 1.21 & 346 & 241 \\
\hline Ground wheat & 86.88 & 12.04 & 1.42 & 2.32 & 1.71 & 1.22 & 95 & 114 \\
\hline Wheat bran & 88.30 & 14.66 & 3.98 & 6.88 & 4.19 & 0.93 & 109 & 96 \\
\hline Evening primrose oil cake & 87.91 & 21.31 & 7.69 & 22.73 & 7.56 & 0.62 & 157 & 133 \\
\hline Whole milk & 12.13 & 3.12 & 4.19 & - & 7.5 & 1.92 & 257 & 300 \\
\hline Meadow hay & 81.6 & 9.55 & 1.84 & 27.19 & 5.38 & 0.64 & 73 & 74 \\
\hline \multicolumn{9}{|c|}{ Concentrate mixture for groups } \\
\hline $\mathrm{C}$ & 87.2 & 15.96 & 2.11 & 4.27 & 4.8 & 1.12 & 124 & 122 \\
\hline $\mathrm{Pl}$ & 87.6 & 16.12 & 3.38 & 7.71 & 5.69 & 1.00 & 124 & 116 \\
\hline $\mathrm{P} 2$ & 87.7 & 15.70 & 4.56 & 11.05 & 6.40 & 0.87 & 117 & 108 \\
\hline
\end{tabular}

1 IZ, 1993: UFL - unit for milk production; PDI - protein truly digestible in the small intestine; PDIN - PDI dependent on ammonia-N amount; PDIE - PDI dependent on energy amount

TABLE 3

Daily intake of feed and nutrients

\begin{tabular}{lcccr}
\hline & \multicolumn{3}{c}{ Groups } & SE \\
\cline { 2 - 4 } Item & $\mathrm{C}$ & $\mathrm{P} 1$ & $\mathrm{P} 2$ \\
\hline Concentrate mixture, $\mathrm{kg}$ & $1.75^{\mathrm{a}}$ & $1.94^{\mathrm{ab}}$ & $2.12^{\mathrm{b}}$ & 0.37 \\
Dry matter, kg & $2.02^{\mathrm{a}}$ & $2.19^{\mathrm{ab}}$ & $2.38^{\mathrm{b}}$ & 0.32 \\
Crude protein, g & $389^{\mathrm{a}}$ & $422^{\mathrm{ab}}$ & $443^{\mathrm{b}}$ & 58.73 \\
PDI, g & 303 & 314 & 324 & 40.00 \\
${\text { PDIN }-\mathrm{PDI}^{\mathrm{b}}, \mathrm{g}}_{\mathrm{UFL}^{1}}$ & +4 & +4 & -2 & 1.47 \\
\hline
\end{tabular}

$\mathrm{a}, \mathrm{b}-\mathrm{P} \leq 0.01$

${ }^{1}$ see Table 2

\section{DISCUSSION}

The beneficial influence of increasing the proportion of evening primrose oil cake in the concentrate mixture on its intake in calves is difficult to explain. May be evening primrose, classified as an herb, contains some aromatic substances or other components advantageously affecting feed palatability and intake. Preparations of herb aroma and taste or herb mixture additives to the diet for animals are 
TABLE 3

Daily intake of feed and nutrients

\begin{tabular}{|c|c|c|c|c|}
\hline \multirow{2}{*}{ ltem } & \multicolumn{3}{|c|}{ Groups } & \multirow{2}{*}{$\mathrm{SE}$} \\
\hline & $\mathrm{C}$ & P1 & $\mathrm{P} 2$ & \\
\hline \multicolumn{5}{|l|}{ Liveweight, $\mathrm{kg}$} \\
\hline initial & 44.0 & 44.1 & 44.5 & 4.78 \\
\hline at 56 th day of life & 82.5 & 81.8 & 82.3 & 6.92 \\
\hline final & 82.5 & 81.8 & 82.3 & 6.92 \\
\hline Daily gain for $56^{\text {th }}$ day of life, $g$ & 768 & 764 & 771 & 120 \\
\hline \multicolumn{2}{|l|}{ Daily gain for whole experimental } & 892 & 852 & 115 \\
\hline \multicolumn{5}{|c|}{$\begin{array}{l}\text { Feed utilization for whole experimental } \\
\text { period, per gain of } 1 \mathrm{~kg}\end{array}$} \\
\hline concentrate mixture, $\mathrm{kg}$ & $1.98^{\mathrm{aA}}$ & $2.17^{\mathrm{aA}}$ & $2.49^{\mathrm{bB}}$ & 0.27 \\
\hline dry matter, $\mathrm{kg}$ & $2.30^{\mathrm{aA}}$ & $2.45^{\mathrm{a}}$ & $2.77^{\mathrm{bB}}$ & 0.23 \\
\hline crude protein, g & $443^{\mathrm{A} \wedge}$ & $473^{\mathrm{AAB}}$ & $522^{\text {bH }}$ & 43.34 \\
\hline PDI, g & $334^{\text {aA }}$ & $352^{\mathrm{abAB}}$ & $379^{\mathrm{bB}}$ & 30.30 \\
\hline UFL', g & $2.86^{\mathrm{aA}}$ & $3.00^{\mathrm{aAH}}$ & $3.31^{\mathrm{bB}}$ & 0.27 \\
\hline
\end{tabular}

$\mathrm{a}, \mathrm{b}-\mathrm{P} \leq 0.05 ; \mathrm{A}, \mathrm{B}-\mathrm{P} \leq 0.01$

${ }^{\prime}$ see Table 2

sometimes used to stimulate feed intake (Bradley, 1978; Ryś and Urbańczyk, 1983; Wójcik et al., 1984). As compared with the control group, increased feed intake in calves fed diets with evening primrose oil cake did not cause significant differences in calf liveweight gains but worsened feed efficiency, particularly in group P2 with the $33 \%$ proportion of evening primrose oil cake in the diet. In spite of higher feed intake in this group, the body liveweight gains were similar in all groups but feed efficiency worse than in remaining groups.

The lack of differences in body liveweight gain between groups of calves in spite of the low content of lysine in evening primrose oil cake could probably be explained by a complementary amount of amino acids in the diets - the lysine-rich but methionine-deficient soyabean oil meal and evening primrose oil cake, which is low in lysine but high in methionine (Stasiniewicz et al., 1998). May be the high $\gamma$-linolenic acid content in evening primrose oil cake, a biologically active component, had some influence on improving the performance of calves in group P1 and P2 (Horrobin, 1990).

The protein of evening primrose has a low solubility and digestibility (Szymczak and Drzewicka, 1992; Stasiniewicz et al., 1998) and, as a consequence of that, the physiological availability of such a protein might be low. The higher proportion of fat in the concentrate mixture with $33 \%$ of cake could also negatively effect crude fibre digestibility (Kowalczyk et al., 1977; Murphy et al., 1990; Strzetelski et al., 1993). 


\section{CONCLUSIONS}

The results of the experiment indicate that evening primrose oil cake as a component of a diet replacing soyabean meal for calves increases feed intake but without a concomitant increase of body liveweight gain. The feed efficiency of such diets was worse than in isonitrogenous diet with soyabean meal.

\section{REFERENCES}

AOAC, 1990. Association of Official Analytical Chemists, Official Methods of Analysis. 15th Edition. Arlington, VA

Bradley B.L., 1978. Animal flavour types and their specific in compound feeds by species and age. First International Symposium on Palatability and Flavour Use in Animal Feeds. Zurich, pp. 125-134

Dixon R.M., Hosking B.J., 1992. Nutritional value of grain legumes for ruminants. Nutr. Res. Rev. $5,19-43$

Hanczakowski P., Szymczyk B., 1993. The nutritive value of the residues remaining after oil extraction from seeds of evening primrose (Oenothera biennis L.). J. Sci. Food Agric. 63, 375-376

Horrobin D.F., 1990. $\gamma$-linolenic acid: An intermediate in essential fatty acid metabolism, with potential as an ethical pharmaceutical and as food. Rev. Contemp. Pharmatother. 1, 1-45

IZ, 1993. Institute of Animal Production. Standard of Cattle, Sheep and Goat Nutrition (in Polish), Omnitech Press, Warszawa (Poland)

Kowalczyk J., Ørskov E.R., Robinson J..J., Stewart C. S., 1977. Effect of fat supplementation on voluntary intake and rumen metabolism in sheep. Brit. J. Nutr. 32, 251-257

Michalet-Doreau B., Verité R., Chapoutot P., 1987. Métodologie de mesure de la degradabilité in sacco d'azote des aliments dans le rumen. Bull. Tech. CRZV Theix, INRA 69, 5-7

Murphy J.J., McNeill G.P., Connolly J.F., Gleson P.A., 1990. The effect on cow performance and milk fat composition of including full fat soyabean and rapeseed in concentrate mixture for lactating dairy cows. J. Dairy Res. 57, 295-306

Ryś R., Urbańczyk J., 1983. The effectiveness of flavouring piglet feed with a liquid Pig Nectar. Acta Agr. Silv., Ser. Zoot. 22, 73-81

Stasiniewicz T., Niwińska B., Strzetelski J., Kowalczyk J., Maciaszek K., Bilik K., 1998. Nutritive value of evening primrose (Oenothera paradoxa) cake for ruminants. J. Anim. Feed Sci. 7, 187-195

Strzetelski J.A., Krawczyk K., Kowalczyk J., Stasiniewicz T., Osięgłowski S., Lipiarska E., 1998a. Performance and body fat composition of fattening bulls fed diets with evening primrose (Oenothera paradoxa) oil cake. J. Anim. Feed Sci. 7, 261-271

Strzetelski J.A., Kowalczyk J., Krawczyk K., Stasiniewicz T., Lipiarska E., 1998b. Evening primrose (Oenothera paradoxa) oil cake or ground rape seed supplement to the diets for dairy cows. J. Anim. Feed Sci. 7, 365-375

Strzetelski J.A., Stasiniewicz T., Lipiarska E., Stankiewicz B., 1993. The effect of heat treated rapcseed included to concentrate mixtures on cow performance, milk fat composition and rumen fermentation (in Polish). Roc7. Nauk Zoot. 20, 107-121 
Szymczak J., Drzewicka M., 1992. Nutritional value of Oenothera paradoxa seed presscakes (in Polish) In: Procecdings of Symposium : Evening Primrose Oil in Prophylaxis and Therapy. Łódź (Poland), pp. 58-65

Wójcik S., Błaziak S., Wideński K., Zawiślak K., 1984. Nutritional usefulness some of herbs offals (in Polish). Biul. inf. Przem. Pasz. 23 (3), 30-36

\section{STRESZCZENIE}

\section{Zastosowanie wytloczyn $\mathrm{z}$ nasion wiesiolka $\mathrm{w}$ wychowie cieląt}

Wpływ zastapienia poekstrakcyjncj śruty sojowej wytłoczynami z nasion wiesiołka (Oenothera paradoxa) na wyniki odchowu cieląt badano w doświadczeniu na 60 cielętach-buhajkach od 7 do 120-tego dnia żcia. Buhajki podzielono na 3 grupy po 20 i żywiono według systemu INRA skarmiając mleko pełne $w$ ilości około $350 \mathrm{~kg} /$ cielę do 56-tego dnia życia oraz mieszanki treściwe o różnym udziale wytłoczyn z. wiesiołka: 0 (grupa kontrolna C), 16,5 (grupa doświadczalna P1) i 33\% (grupa doświadczalna P2) i $0,2 \mathrm{~kg} /$ dzień siana ląkowego. Wytłoczyny zastępowały w 50 lub $100 \%$ białko poekstrakcyjnej śruty sojowej w mieszance dla grupy kontrolncj. Micszanki były izoenergetycznce $\mathrm{i}$ izobiałkowe pod względem białka ogólnego i białka trawionego w jelitach. Pobranie mieszanek wynosiło średnio 1,$75 ; 1,94$ i $2,12, \mathrm{~kg} /$ dzień, odpowiednio w grupach $\mathrm{C}, \mathrm{P} 1 \mathrm{i}$ P2, lecz nie znalazło to odzwicrcicdicnia w średnich dziennych przyrostach masy ciała cielat. Były one podobne u buhajków w grupie C i P1 (883 i 892 g, odpowiednio) i nieco niższe w grupie P2 (858), ale różnice te nic były statystycznie istotne. Zużycie mieszanek na kilogram przyrostu masy ciała zwiększało się wraz ze wzrostem udziału wytłoczyn w mieszankach i wynosiło w grupie C 1,98; P1 2,2 i $\mathrm{P} 22,5 \mathrm{~kg}$. 